\title{
Association of Institutes for Bee Research Report of the 57th Seminar in Bochum 23-25 March 2010
}

\section{Arbeitsgemeinschaft der Institute für Bienenforschung e.V. 57. Jahrestagung in Bochum vom 23.-25. März 2010}

List of reports $(*$ after the title indicates that an abstract of this report is published)

Verzeichnis der Referate $(*$ nach dem Titel bedeutet, dass zu diesem Titel eine Zusammenfassung aufgeführt ist)

\section{Invited talk \\ Einführungsvortrag}

1. Bees, pollination and global change. $I$. Steffan-Dewenter

Bienen, Bestäubung und globaler Wandel.

\section{Ecology, pollination, plant protection}

\section{Ökologie, Bestäubung, Pflanzenschutz}

2. Uptake of corn pollen, colony population dynamics and foraging strategies of honey bees in agricultural landscape with different areas of corn growing. N. Danner, S. Härtel, I. Steffan-Dewenter Maispolleneintrag, Volksentwicklung und Sammeldistanzen von Honigbienen in Agrarlandschaften mit unterschiedlicher Maisanbaufläche.

3. The use of maize pollen by the honeybee. $T$. Kustermann, D. de Craigher, G. Liebig*

Untersuchungen zur Nutzung und Bedeutung von Maispollen für die Honigbiene.

4. Effects of a pure maize pollen diet on the honeybee. N. Höcherl, I. Illies, R. Siede, J. Tautz* Auswirkungen einer einseitigen Maispollenernährung auf die Honigbiene.

5. Pollen supply and honey bee population development. G. Liebig, P. Aumeier, O. Boecking* Kleckern oder Klotzen? Pollenversorgung und Volksentwicklung.

6. A honeybee larvae in-vitro test on multiple transgenic maize pollen. H. Hendriksma, S. Härtel, I. Steffan-Dewenter
Ein in-vitro Test mit Bienenlarven für multitransgene Maispollen.

7. Bees for berries: Opportunities and problems. H.M.T. Hokkanen, I. Menzler-Hokkanen*

Die Honigbiene als Nutztier in der Beerenproduktion.

8. Insecticides in oilseed rape: Do they influence the ability of honey bees to find their way home?

$J$. Teglas, K. Wallner

Rapsinsektizide - beeinflussen sie das Heimfindevermögen von Bienen?

9. The release of active ingredients from seed dressing in guttation droplets: a risk for honey bees? J. Reetz, K. Wallner

Freisetzung von Beizmittelwirkstoffen in Guttationeine Gefährdung für die Honigbienen?

10. The effect of Pyrrolizidin alcaloids on larvae of the honey bee. A. Reinhard, T. Beuerle, T. Hartmann, M. Janke, W. von der Ohe

Wirkung von Pyrrolizidin-Alkaloiden auf Larven der Honigbiene.

\section{Genetics, breed}

\section{Genetik, Zucht}

11. The identification of diagnostic expression patterns for the hygienic behavior of the honey bee. T. Gempe, S. Stach, K. Bienefeld, M. Beye

Identifizierung diagnostischer Expressionsmuster für das Hygieneverhalten der Honigbiene.

12. QTL- Mapping of larval Varroa resistance. D. Behrens, Q. Huang, C. Gessner, E. Frey, P. Rosenkranz, R.F.A. Moritz

QTL-Mapping für individuelle Varroa-Resistenz bei Bienenlarven.

13. The "thelytoky causing element": a splicingregulatory motif suspected of causing selfish behaviour in the honeybee Apis mellifera. A. Jarosch, R.F.A. Moritz 
Das „Thelytokie-auslösende Prinzip“: Eine Splicing-Regulation, die möglicherweise egoistisches Verhalten bei der Honigbiene Apis mellifera auslöst.

14. Population genetic analysis of sex alleles in a finite honeybee population. M.G. Lattorff, $M$. Medrano, M.J. Duchateau, R.F.A. Moritz.

Populationsgenetische Analyse der Sexallele in einer begrenzten Honigbienenpopulation.

15. Measurements of the gene expression of pooled samples - Experimental designs for the tests of bias free hypotheses. $H$. Rudolf

Genexpressionsmessungen an gepoolten ProbenVersuchspläne für verzerrungsfreie Hypothesentests.

16. Validation of rapid tests for the control quality control of defrosted drone sperm. J. Wegener, G. Kamp, K. Müller, K. Bienefeld

Validierung von Schnelltests zur Qualität aufgetauten Drohnenspermas.

17. Cross species amplification of microsatellite loci in Apidae - A tool for phylogenetic analyses. M. Müller, E. Stolle, F.B. Kraus, R.F.A. Moritz

„Cross species-Amplifikation" von MikrosatellitenLoci bei Apidae: Ein Werkzeug für phylogenetische Analysen.

\section{Physiology, behavior}

\section{Physiologie, Verhalten}

18. Dynamics of the information transfer between the brain hemispheres of the honeybee during memory retrieval. J. Fischer, B. Grünewald* Dynamik des Informationstransfers zwischen den Hirnhemisphären während des Gedächtnisabrufs der Honigbiene.

19. Diagnostic Radioentomology (=DR) as a tool to investigate cryptic honeybee behaviour in winter cluster. B. Dainat, M.K. Greco, P. Neumann Diagnostische Radioentomologie als eine Möglichkeit zur Untersuchung von verborgenen Verhaltensweisen von Honigbienen in der Wintertraube.

\section{Bees pathology}

\section{Bienenpathologie}

20. Stage and sex specific release of the sex pheromone in Varroa destructor. T. Ziegelmann, P. Rosenkranz.

Stadien- und geschlechtsspezifische Freisetzung des Sexualpheromons bei Varroa destructor.
21. Sublethal effects of oxalic acid on Apis mellifera L. (Hymenoptera: Apidae): Pharmacodynamics. M. Raddatz, E. Rademacher*

Subletale Wirkungen der Oxalsäure auf Apis mellifera: Pharmakodynamik.

22. Sublethal effects of oxalic acid on Apis mellifera L. (Hymenoptera: Apidae): Changes in behavior and longevity. S. Schneider, E. Rademacher* Subletale Effekte der Oxalsäure auf Apis melliferaVeränderungen im Verhalten und der Lebensdauer.

23. Long term monitoring of acaricide residues in Swiss bees wax. C. Kast

Langzeitmonitoring von Akarizid-Rückständen in schweizer Bienenwachs.

24. Investigations into the suitability of entomopathogenic fungi and the identification of hyperparasitic fungi as antagonists of Varroa destructor. M. Holt, P. Aumeier, W.H. Kirchner*

Untersuchungen zur Eignung entomopathogener und zur Identifizierung hyperparasitärer Pilze als Varroaantagonisten.

25. Prevalence of Nosema spp. in Germany and relation with colony losses. S. Gisder, E. Genersch* Vorkommen von Nosema spp. in Deutschland in Zusammenhang mit Völkerverlusten.

26. Provisional results after five years of the German Honey Bee Montoring Program and continuation of the project. A. Schroeder

Zwischenergebnisse nach 5-jähriger Laufzeit des Deutschen Bienenmonitorings und Fortführung des Projekts.

27. European cooperation within the COLOSS project: the role of genotype and environment for honey bee vitality. M. Meixner, R. Büchler

Europäische Kooperation im Rahmen des COLOSS- Projekts: welche Rolle spielen Genotyp und Umwelt für die Vitalität von Honigbienen?

28. The FAO database and the bee decline in Europe. R.F.A. Moritz

Die FAO Datenbank und der Rückgang der Bienen in Europa.

29. Unveiled through counting - Testing beekeeping management techniques via bees' population analysis, the $\mathrm{BiV}$ - project. $P$. Aumeier, G. Liebig, O. Boecking*

Durch Zählen an den Tag gebracht - Betriebsweisenvergleich auf der Basis von Populationsschätzungen, das BiV- Projekt im zweiten Jahr. 


\section{Other hymenopterans}

\section{Andere Hymenopteren}

30. Mating frequency and conflict over male production in the tropical bumblebee Bombus wilmattae. F.B. Kraus, A. Huth-Schwarz, A.L. Gutiérrez, R.F.A. Moritz

Paarungshäufigkeit und Konflikte bei der Erzeugung von Männchen bei der tropischen Hummel Bombus wilmattae.

31. Immune gene expression analysis in the bumble bee Bombus terrestris. S. Erler, M. Popp, M. Lattorff

Expressionsanalyse von Immungenen bei der Hummel Bombus terrestris.

\section{Posters}

Poster

\section{Ecology, pollination, plant protection}

\section{Ökologie, Bestäubung, Pflanzenschutz}

32. Impacts of transgenic proteins, pollen and colony affiliation on survival and longevity of honeybee workers. A. Kästner, S. Härtel, I. SteffanDewenter

Der Einfluss von transgenen Proteinen, Pollen und Volkszugehörigkeit auf das Überleben und die Lebensdauer von Arbeiterinnen der Honigbiene.

33. Spraying boron into blooming oilseed rape a risk for honey bees? W. Dyrba, T. Augustin, R. Siede*

Bordüngung in die Rapsblüte- ein Risiko für die Biene?

34. An immunotoxicological study of common pesticides on honey bees. J. Pinkas, R. Siede, M. Meixner, R. Büchler*

Untersuchungen zur Immunrelevanz ausgewählter Pestizide auf die Honigbiene.

35. Effects of the neonicotinoids clothianidin und imidacloprid on the foraging behavior of Apis mellifera carnica. C. Schneider, B. Grünewald, J. Tautz, S. Fuchs

Wirkung der Neonicotinoide Clothianidin und Imidacloprid auf das Sammelverhalten von Apis mellifera carnica.

\section{Genetics, breeding}

\section{Genetik, Zucht}

36. Expected advantages of Genomic Selection in the honeybee. P. Gupta, N. Reinsch, A. Spötter, T. Conrad, K. Bienefeld
Zu erwartende Vorteile der genomischen Selektion bei der Honigbiene.

37. Heritabilities of and genetic correlations between two Varroa resistance traits both influenced by direct and maternal effects. K. Ehrhardt, $R$. Büchler, K. Bienefeld

Die Erblichkeiten von und die genetischen Korrelationen zwischen zwei Merkmalen der Varroaresistenz, die beide von direkten und maternalen Effekten beeinflusst werden.

38. Development of a SNP-Assay for Varroa tolerance in the honey bee. A. Spötter, P. Gupta, N. Reinsch, F. Zautke, K. Bienefeld*

Entwicklung eines SNP- Assays zur Varroatoleranz der Honigbiene.

39. Is the number of antennal sensillae involved in odor detection higher in honey bees selected for Varroa-resistance? C. Schöning, K. Bienefeld Ist bei Honigbienen, die auf die Varroa- Resistenz gezüchtet wurden, die Anzahl der bei der Duftwahrnehmung beteiligten antennnalen Sensillen höher?

40. Better strong than related - decisions about the selection of larvae in queen breeding. $S$. Al-Kahtani, K. Bienefeld

Lieber kräftig als verwandt- Entscheidungen bei der Auswahl von Larven für die Könniginnenzucht.

41. Influence of the position and number of Apidea type mating hives on the mating success of Apis mellifera carnica queens on the island mating station Unije, in May 2009. D. Sekulja*

Einfluss von Aufstellung und Anzahl von Apidea Begattungskästchen auf den Paarungserfolg von Apis mellifera carnica Königinnen auf der Inselbelegstelle Unije im Mai 2009.

\section{Physiology, behavior}

\section{Physiologie, Verhalten}

42. Live-cell-imaging and physiological characterization of brain-cell-transmitter-receptors. $S$. Himmelreich, M. Hähnel, B. Grünewald*

Bildgebende Verfahren und physiologische Charakterisierung von Transmitterrezeptoren in Gehirnzellen.

43. Analysis of honeybee locomotion behavior. G. Radspieler, M. Szopek, S. Hahshold, R. Thenius, T. Schmickl, K. Crailsheim*

Analyse des Bewegungsverhaltens von Honigbienen.

44. Cooperative thermotaxis in honeybees: social gradient vs. temperature gradient. $S$. Hahshold, G. Radspieler, R. Thenius, T. Schmickl, K. Crailsheim* 
Kooperative Thermotaxis bei Honigbienen: Sozialer Gradient vs. Temperaturgradient.

45. Cooperative thermotaxis in honeybees: flexible group behaviour in a dynamic environment. $M$. Szopek, G. Radspieler, R. Thenius, T. Schmickl, K. Crailsheim*

Kooperative Thermotaxis bei Honigbienen: flexibles Gruppenverhalten in einer dynamischen Umwelt.

46. Behavior of worker bees towards related and non-related queens during their introduction into queenless colonies. S. Masry, M.K. Zakour, K. Bienefeld

Verhalten von Arbeitsbienen gegenüber verwandten und nicht-verwandten Königinnen beim Einweiseln.

47. Honeybees are not tea drinkers. D. Ahrens, N. Höcherl, H. Gätschenberger, K. Azzami, J. Tautz*

Bienen sind keine Teetrinker.

48. Delayed development of artificially reared honeybees. U. Riessberger-Gallé, J. Vollmann, K. Crailsheim (Graz)*

Verzögerte Entwicklung von künstlich aufgezogenen Honigbienen.

49. The phospho-lipid composition of honeybee sperm. K. Teuber, J. Wegener, K. Bienefeld, J. Schiller, K. Müller

Die Phospholipid-Zusammensetzung der Spermien von Honigbienen.

\section{Bees pathology}

\section{Bienenpathologie}

50. Viruses associated with oocyte degeneration in Apis mellifera L. queens. L. Gauthier, M. Ravallec, M. Tournaire, F. Cousserans, M. Bergoin, J.R. de Miranda

Viren die mit einer Oozytendegeneration in Apis mellifera L. Königinnen assoziiert sind.

51. NRPS and PKS in Paenibacillus larvae. E. Garcia-Gonzales, J. Nachtigall, R. Borriss, R. Süssmuth, E. Genersch*

NRPS und PKS in Paenibacillus larvae.

52. Successfull manipulation of Paenibacillus larvae. L. Poppinga, E. Genersch*

Erfolgreiche Manipulation von P. larvae.

53. Expression of Plt, a ADP- ribosylating toxin of Paenibacillus larvae. L. Poppinga, A. Fünfhaus, E. Genersch*

Expression von Plt, einem ADP-ribosylierenden Toxin von P. larvae.
54. Proteome analysis (2D-SDS-PAGE) of $P$. larvae. A. Fünfhaus, E. Genersch* Proteomanalyse (2D-SDS-PAGE) von P. larvae.

55. Horizontal transmission of DWV to adult bees. N. Möckel, S. Gisder, E. Genersch*

Horizontale Übertragung von DWV auf erwachsene Bienen.

56. Varroa reproduction: Chronological course and the search for activating substances within the honey bee brood. R. Odemer, E. Frey, P. Rosenkranz Varroa-Reproduktion - zeitlicher Verlauf und Suche nach den aktivierenden Substanzen in der Bienenbrut.

57. Intraspecific interactions of Varroa destructor during the reproductive cycle. C. Bosch, P. Aumeier, W.H. Kirchner*

Intraspezifische Interaktionen bei Varroa destructor in der reproduktiven Phase.

58. Histopathology of Nosema- infected bees. $N$. Möckel, S. Gisder, E. Genersch*

Histopathologie von Nosema spp. infizierten Bienen.

59. Harmful fading away or beneficial shakeout? A two-years-study of population dynamics of honey bee colonies infected with Nosema ceranae. P. Aumeier, J. Lipka, S. Niederdrenk, K. Porbeck, E. Genersch, O. Boecking, G. Liebig, W.H. Kirchner* Schwindsucht oder Gesundschrumpfung? ZweiJahres-Studie zur Populationsdynamik von Bienenvölkern bei Befall mit Nosema ceranae.

60. Is Nosema ceranae really a new bee killer? Course of infection and survival rates in cage tests. A. Larue, L. Steiner, P. Rosenkranz

Ist Nosema ceranae wirklich ein neuer $\mathrm{Bi}$ enenkiller? Infektionsverlauf und Überlebensraten im Käfigtest.

61. Honey bee colony development and infestation with Nosema spec. after manipulation of the brood during spring 2009. D. de Craigher, G. Liebig*

Volksentwicklung und Verlauf des Nosemabefalls nach Brutmanipulation im Frühjahr 2009.

62. Pathogenesis and behaviour of honey bees infected with Nosema ceranae. S. Deckert, P. Aumeier, W.H. Kirchner*

Infektionsverlauf und Verhalten mit Nosema ceranae infizierten Bienen.

63. Interactions between Nosema ceranae and bacteria in honeybee workers. U. Hartmann, J.-D. Charrière, J. Pflugfelder, M. Ladesani, P. Neumann Wechselwirkungen zwischen Nosema ceranae und Bakterien in Arbeiterinnen von Honigbienen. 
64. Overwintering in test and monitoring colonies 2009/2010. G. Liebig, D. de Craigher

Die Überwinterung von Versuchs- und Monitoringvölkern 2009/2010.

65 . First global estimation of honey bee colony losses. K. Crailsheim, R. Brodschneider*

Erhebung der Völkerverluste auf der Apimondia 2009.

66. A closer look - Honey bee colony losses in Germany in 2009/10. P. Aumeier, O. Boecking, G. Liebig*

Nachgefragt - Völkerverluste in Deutschland 2009/10.

\section{Bee practices, bee products}

\section{Imkerpraxis, Bienenprodukte}

67. Investigations in the segregation of honey. $M$. Danne, B. Lichtenberg-Kraag, B. Senge

Untersuchung der Entmischung von Honig.

68. The pollen spectrum in town honeys from Berlin. E. Etzold, B. Lichtenberg-Kraag

Das Pollenbild Berliner Stadthonige.

69. Propolis extraction from the inner hive wall surface. N. Kunz, R. Müller, K. Wallner, A. Schroeder

Propolisgewinnung an der Zargeninnenwand.

\section{Other hymenopterans}

\section{Andere Hymenopteren}

70. The Good, the Bad and the Ugly: Bumblebees, crithidia and virulence. S. Parsche, M.G. Lattorff

Die Guten, die Schlechten und die Hässlichen: Hummeln, Crithidia und Virulenz.

\section{Free topics}

\section{Freie Themen}

71. Towards robust estimations of population size from digital images. T. Schüttler, B. Meffert, $U$. Knauer

Einer belastbaren Schätzung von Populationsgrößen aus digitalen Bildern entgegen.

72. Apiculturally important plants in Cameroon. F.N. Tchuenguem, D. Brückner

Für die Bienenhaltung wichtige Pflanzen in Kamerun.

73. Bee legs and feathers as natural model for absorbent textiles. V. Grabarek, H. Schmied, D. Wittmann*

Bienenbeine und Federn als natürliches Modell für absorbierende Textilien.
74. World Varroa Challenge Toulouse, France. J. Kefuss*

Toulouse, Frankreich als weltweite Herausforderung für Varroa.

75. "Bees deserve attention" - a project to recruit new target groups for the topic of bees. $G$. Brunnemann, M. Meixner

„Bienen verdienen Aufmerksamkeit“ - ein Projekt zur Gewinnung neuer Zielgruppen für das Thema Bienen.

\section{Abstracts}

3. The importance of corn pollen and its utilization by honey bees. T. Kustermann, $D$. de Craigher, G. Liebig (Apicultural State Institute, University of Hohenheim, 70593 Stuttgart, Germany)

Due to the increasing cultivation of genetically modified corn varieties and the dressing of corn seed with systemic insecticides, the attractiveness of corn pollen for honey bees is of particular interest. In the recent literature, the value of corn pollen is considered by some to be "insignificant", while others find it "very important" for honey bees. As a consequence of the massive intoxication of honey bees in the Rhine Valley in the spring 2008, specific investigations on corn pollen have been carried out during the years 2008 and 2009. From 46 colonies established at three apiaries along the Rhine Valley and one apiary near Stuttgart, pollen was collected in pollen traps and the percentage of corn pollen macroscopically determined. The daily proportion of total pollen that consisted of corn pollen ranged from $0-100 \%$ in individual colonies. Also, the time course for the collection of corn pollen varied significantly according to the weather conditions. The presence of other attractive pollen sources in the vicinity of the experimental bee hives reduced the amount of corn pollen collected. At one apiary in the Rhine Valley, most of the colonies foraged nearly exclusively on asparagus pollen. However, in other areas with asparagus fields this extreme dietary preference was not observed. Further research is required to determine the factors that influence the attraction of certain pollen sources for honey bees. At one apiary, which was somewhat isolated from the next corn field, we found that foragers would fly at least $1.25 \mathrm{~km}$ to collect corn pollen, even if other pollen sources were available in the closer vicinity. Compared to colonies in the immediate vicinity to this corn field, the percentage of collected corn pollen did not vary significantly 
(29\% in $1.25 \mathrm{~km}$ distance vs. $38 \%$ in the immediate vicinity, 3 weeks average). During the main corn blooming period in 2009 more than $50 \%$ of the total collected pollen was corn pollen. Therefore, in summary it can be stated that corn pollen is definitively attractive to honey bees.

4. Effects of a pure maize pollen diet on the honeybee. $N$. Höcherl ${ }^{1,2}$, I. Illies $^{2}, R$. Siede ${ }^{3}$, J. Tautz ${ }^{1}\left({ }^{1}\right.$ BEEgroup, Biozentrum Universität Würzburg, 97074 Würzburg, Germany; ${ }^{2}$ LWG, Fachzentrum Bienen, 97209 Veitshöchheim, Germany; ${ }^{3}$ LLH Bieneninstitut, 35274 Kirchhain, Germany)

Farming has become increasingly intensive during the past decades. As a consequence, the variety of flowering plants in modern agro-ecosystems has decreased dramatically and bees have problems to find sufficient amounts of pollen. To mimic the effects of poor pollen supply we established three groups of three mini bee colonies each in flight tents and fed them with (a) corn pollen only (hand collected); (b) pollen substitutes (van der Steen, 2007); and (c) mixed pollen (collected by bees). The availability of carbohydrates was not restricted. We measured the amount of consumed pollen, the brood mortality, the lifespan, and the immunocompetence after injection of Paenibacillus larvae. Bees exclusively fed with corn pollen consumed much more pollen, but were less successful in brood rearing (25\% vs. $39 \%$ brood survival) and less longlived than bees fed with mixed pollen ( $25 \mathrm{~d}$ vs. $31 \mathrm{~d}$ mean life). Further studies using disk diffusion tests and the q-RT-PCR after artificial infection with $P$. larvae did not show differences with respect to the immune-related proteins in the hemolymph of differently fed bees and the immune-relevant hymenoptaecin gene expression, respectively. Afterwards the nutritive value of each diet was investigated. A striking finding was the low content of histidine in corn and the low levels of essential amino acids in the pollen substitute. The latter has been proved to be unsuitable for bees as colonies fed with that diet had a $93 \%$ brood mortality rate. Our experiments show that a pure corn pollen diet has negative influences on lifespan and brood success of a honey bee colony. However, this crop could be an emergency supply in times of limited pollen availability. Our results emphasize strongly the importance of a balanced and continuous pollen supply over the total brood season for honey bee colonies.

5. Pollen supply and honey bee population development. G. Liebig $^{1}$, P. Aumeier ${ }^{2}, O$.
Boecking ${ }^{3}\left({ }^{1}\right.$ Apicultural State Institute, University of Hohenheim; ${ }^{2}$ Ruhr-Universität Bochum; ${ }^{3}$ Institut für Bienenkunde, Celle)

In 2009 population development of 112 honey bee colonies, located at 9 apiaries in Northern, Western and Southern Germany, respectively, was recorded according to the Liebefeld method. Only some of the colonies had direct access to oilseed rape. Estimations of the colony size and the amount of stored pollen were performed at regular intervals of 21 days from March until October. The amount of open and sealed brood cells revealed no differences amongst the three regions. The number of cells filled with pollen increased from 5000 in March up to 13000 at the beginning of May and subsequently decreased until mid of September to 4000 cells. During the breeding period the pollen requirements of the colonies were covered by continuous collection of pollen. During the blooming period of oilseed rape, the colonies had access to plenty of pollen even if no rape was present in an area up to $3 \mathrm{~km}$ around the apiaries. Even after the end of the blooming period of oilseed rape there was no general lack of pollen. Therefore, the honey bee colony is a reliable indicator to evaluate the pollen sources which are available in the vicinity of the apiary. Considering the amount of brood from April to August, the mean storage period of pollen is supposed to be approximately one week. Hence, pollen samples for the analysis of pesticides suspected of causing exceptional bee losses have to be taken immediately, as otherwise the contaminated pollen may be consumed.

7. Bees for berries: opportunities and problems. H.M.T. Hokkanen*, I. Menzler-Hokkanen (Department for Agricultural Sciences, Box 27, 00014 University of Helsinki, Finland)

Bees are essential pollinators for many berry crops, and the honeybee is the only managed pollinator suitable for large berry fields. Despite the proven benefits, only a few berry-growers take advantage of pollination services. This is likely to change as our research has demonstrated high added value in using bees for targeted biocontrol of the grey mould fungus in strawberries and raspberries. On-farm experiments in Finland during the past four years have shown that bee-mediated biocontrol is reliable, inexpensive, and environmentally friendly: under no conditions were the standard fungicide treatments (sometimes up to 5 times) more effective than biocontrol. In contrast, marketable yield of strawberries was often highest in the biocontrol-only -treatment. Together with 
improved pollination, efficient biocontrol of grey mould can yield twice as much marketable fruits compared with the untreated controls. Our research also showed that honeybees were frequent visitors at strawberry flowers, averaging more than one visit/hour in every strawberry flower, regardless of the ambient air temperature $\left(+12^{\circ} \mathrm{C}\right.$ upwards $)$, time of the day (with highest activity around noon), and the blossoming season (from the beginning till the end, including periods with concurrent blossoming of other, highly attractive bee-plants). We anticipate that, increasingly, keeping bees will become part of the professional skills of all berry growers, due to the superior economic performance of the "beesberries' interaction.

18. Dynamics of the information transfer between the brain hemispheres of the honeybee during memory retrieval. J. Fischer ${ }^{1}, B$. Grünewald ${ }^{1}$ ( ${ }^{1}$ Institut für Bienenkunde, Polytechnische Gesellschaft Frankfurt am Main, GoetheUniversität Frankfurt am Main, Germany)

During unilateral conditioning of the proboscis extension reflex (PER) bees learn a specific odor only on the trained side. This side-specificity is lost after several hours and the bees respond with the PER during odor presentations on both sides. To determine if this results from a transfer of information during memory consolidation or during retrieval we used a local anesthetic (procaine) to block neural activity in the $\alpha$-lobe, an output region of the mushroom body. Procaine is a local anesthetic which reversibly inhibits the signaling within the targeted brain region for approximately three hours. It was injected directly into the ipsi- or contralateral $\alpha$-lobe $24 \mathrm{~h}$ after the unilateral training. Under this treatment there should be no more information transfer between the two mushroom bodies. During and after local anesthesia the response rates to the stimulation with the learned odor on either the trained (ipsilateral) or the untrained (contralateral) hemisphere were measured. Injections of procaine into the ipsilateral $\alpha$-lobe reduced the probability of the conditioned response (CR) after stimulation of the contralateral side, the ipsilateral hemisphere was not significantly affected by the treatment. A similar effect occurred after injections into the contralateral $\alpha$-lobe, but it was not as strong as after the injection into the ipsilateral $\alpha$-lobe. All effects were reversible and the CR rates recovered $4 \mathrm{~h}$ after injection. These results show that the transfer of information to the contralateral (non-trained) hemisphere is not complete, even after memory consolidation. A connection between the two mushroom bodies is required for the contralateral memory retrieval, indicating that the unilateral acquired memory is stored within the ipsilateral mushroom body.

21. Sublethal effects of oxalic acid on Apis mellifera L. (Hymenoptera: Apidae): Pharmacodynamics. M. Raddatz, E. Rademacher (Free University of Berlin, Institute of Biology/Neurobiology, Königin-Luise-Str. 28-30, 14195 Berlin, Germany)

In beekeeping practice oxalic acid dihydrate (OA) is used to control Varroa destructor. Correspondent to the use in the field OA was applied topically in our trials in a dosage of $175 \mu \mathrm{g} / \mathrm{bee}$. To avoid ingestion, the OA solution was sugarfree. After individual treatment of single bees the $\mathrm{pH}$-value of parts of the digestive system and the haemolymph were investigated with acid-base indicator after 1, 24, 48 and 72 hours ( $n=10$ per test and time interval). Furthermore we applied ${ }^{13} \mathrm{C}$ marked $\mathrm{OA}$ in order to identify the acid in the haemolymph by HPLC/MS also after 1, 24, 48 and 72 hours ( $\mathrm{n}=$ 10 per test and time interval, pooled samples, min. 5 bees per sample). The single dermal treatment of OA can cause $\mathrm{pH}$ changes in internal organs and the haemolymph of the bee: in the haemolymph significant differences between test bees and controls were found after all time intervals (MWU, $P \leq 0.05$ ). In the honey sac no significant differences between test bees and controls were found (MWU, $P \geq 0.05$ ): neither an oral intake of OA nor absorption from the haemolymph via the honey sac seems to take place. In the midgut and rectum differences were detected, significantly after 1 and 48 hours and after 24 and 48 hours, respectively (MWU, $P \leq 0.05$ ). After dermal application of ${ }^{13} \mathrm{C}$ of marked OA the substance was not detected in the haemolymph (detection limit $2.5 \mu \mathrm{g}$ ). It is assumed that the Oxalic acid (or parts of the molecule) can get through the cuticula of the bee and can penetrate the epithelium of the midgut respectively rectum. However, it can not to be excluded that the stress of the test situation increased respiration and dehydration, enforcing the effect of $\mathrm{pH}$ value reduction. Due to the fact that acidosis of internal organs and the haemolymph could be shown but the molecule was not found, we assume that $\mathrm{OA}$ could be metabolised in the bee.

22. Sublethal effects of oxalic acid on Apis mellifera L. (Hymenoptera: Apidae): Changes in behaviour and longevity. S. Schneider, E. Rademacher (Free University of Berlin, Institute of Biology/Neurobiology, Königin-Luise-Str. 2830, 14195 Berlin, Germany) 
Oxalic acid dihydrate (OA) is the active ingredient of approved drugs usually used against the parasitic mite Varroa destructor. Although bees have shown a good tolerance to the application form "trickling of $3.5 \%$ OA solution", negative effects of the treatment on honey bees might occur. Therefore, the sublethal effects of OA on division of labor, activity, olfactory learning and the longevity of Apis mellifera were studied. Newly-emerged workers $(\mathrm{n}=300)$ were individually marked. 150 bees were treated with $3.5 \%$ OA solution by topical application before being introduced into a colony. 150 bees were treated with Aqua dest. as controls. Behavioural observations were carried out over 19 days and the longevity of every worker was recorded. To investigate the learning behaviour, foragers $(n=120)$ were trained to respond to an odour in a classical olfactory conditioning (PER). In the experiments, sublethal effects of OA on Apis mellifera workers could be revealed. The treatment caused a significant decrease in worker activity (Wilcoxon, $P \leq 0.005$ ), nursing behaviour (Wilcoxon, $P \leq 0.005)$, and longevity $\left(\chi^{2}\right.$-Test, $P=$ 0.00056 , DF $=1)$. Treated bees also showed significantly more self grooming (Wilcoxon, $P \leq 0.005$ ) and a higher response in the olfactory conditioning than bees of the control group (ANOVA, $P=0.005$, $\mathrm{F}=8.367, \mathrm{DF}=167)$. These results suggest that OA treatment can cause a reduced fitness and, due to the higher response in the PER, damages of the digestive systems are suspected.

24. Investigations into the suitability of entomopathogenic fungi and the identification of hyperparasitic fungi as antagonists of Varroa destructor. M. Holt, P. Aumeier, W.H. Kirchner (Fakultät für Biologie und Biotechnologie, RuhrUniversität Bochum, Germany)

Entomopathogenic fungi have been reported to be effective in the control of Varroa destructor. Here we state that four of these strains of fungi species which have been considered entomopathogenic did not show any effect on mites or honey bee larvae. In addition, Lecanicillium muscarium, Paecilomyces fumosoroseus and Beauveria bassiana caused significantly increased adult bee mortality in an in vitro-assay. Therefore, we started new approaches to find specific acaropathogenic fungi. Over a period of four years a total of 57 bee colonies were checked for the number of adult bees, larval stages and pupae by population estimates every three weeks during the season. In addition, the abundance of Varroa destructor was determined. Varroa mites dropped to the bottom board were collected and placed on sterile water agar in petri dishes after a sterilization of the surface. Mites on petri dishes showing growth of fungi were displaced and cultured separately to prevent the cross-infection of other mites. The results show a negative correlation between relative growth of fungi (i.e. number of fungi per 100 mites collected) and the abundance of mites in the individual colony. Colonies with a high number of fungus growth showed less parasitation by mites indicating that mites of these colonies are infected by potentially specific acaropathogenic fungi. Ongoing investigations concentrate on identification and cultivation of fungi obtained from mites collected from less parasitized colonies to eventually identify specific fungi suitable for a biological control of Varroa destructor.

25. Prevalence of Nosema spp. in Germany and its relationship with colony losses. S. Gisder, E. Genersch (Institute for Bee Research, FriedrichEngels-Str. 32, 16540 Hohen Neuendorf, Germany)

Nosema apis and Nosema ceranae are two microsporidian pathogens infecting the European honey bee, Apis mellifera. These obligate intracellular pathogens infect epithelia cells of the midgut of adult honey bees. Recent studies suggested that $N$. ceranae replaced $N$. apis in the European population of Apis mellifera. Furthermore, Spanish colleagues reported that $N$. ceranae is highly virulent in Apis mellifera, causes severe colony losses and might be implicated in the global decline of honey bees. To evaluate these alarming statements and to assess the situation in Germany, we determined the prevalence of $N$. apis and $N$. ceranae in the northeastern part of Germany by performing a five-year cohort study and analyzing a total of 1997 bee samples from 220 bee keepers, via PCR-RFLP. Our survey revealed that in the analyzed region of Germany $N$. apis is still by far more prevalent than N. ceranae at this point in time. However, we observed a trend of increasing $N$. ceranae prevalence in the last three years. Analyzing the relation between N. apis or N. ceranae infection and colony collapse during the season or winter losses demonstrated no significant $(P \gg 0.05)$ relation between the detection of either nosema infection and colony losses. These results are contradictory to what is reported from Spain and other regions of southern Europe. A possible explanation could be the observed sensitivity of $N$. ceranae spores towards lower temperatures. After storage of spores for 4 days at $4{ }^{\circ} \mathrm{C}$, in vitrogermination of $N$. ceranae spores was totally abolished whereas $80 \%$ of the $N$. apis spores were still 
able to germinate in vitro. We hypothesize that reduced or inhibited germination of $N$. ceranae spores after exposure to low temperatures poses a disadvantage for the assertiveness of this microsporidium in climatic regions characterized by rather long and cold winters.

29. Unveiled through counting - Testing beekeeping management techniques via bees' population analysis: the $\mathrm{BiV}$-project. P. Aumeier ${ }^{1}, G$. Liebig $^{2}$, O. Boecking ${ }^{3}\left({ }^{1}\right.$ Ruhr-Universität Bochum; ${ }^{2}$ Landesanstalt für Bienenkunde Hohenheim; ${ }^{3}$ Institut für Bienenkunde Celle, Germany)

Most honey bee colony losses during winter are due to beekeepers' mismanagement. Starting in March 2008, the "BiV-Projekt" ("Betriebsweisen im Vergleich") tests management techniques that help ensure excellent honey yields and effective control of Varroa destructor, which thus help to reduce winter losses significantly. For the first time, population development of 250 honey bee colonies in Northern, Western, and Southern Germany is simultaneously monitored according to the Liebefeld method. Furthermore, the project involves 110 beekeepers with approximately 1000 colonies to prove the functionality of the management techniques and to impart their findings into practical beekeeping. The tested management approaches differ fundamentally in the way of generating new colonies, in the preparation of colonies for winter, and in the control of Varroa destructor. Extremely strong nucleus colonies established with $7400 \pm 2700$ honey bees ("Celler rotational technique", $C R)$ significantly reduced the swarming tendency of the mother colony $\left(P<0.05, \chi^{2}\right)$ without a reduction of the honey yield $(P>0.05$, $\mathrm{U}$-test). The "Hohenheimer management technique" (HM) integrates artificial queen rearing and produces two to four nucleus colonies per hive. These less-vigorous nucs $(2800 \pm 2000$ bees $)$ proved to be more susceptible to robbing. However, in September, both methods resulted in healthy nucleus colonies of approximately the same size (CR: $9800 \pm 2400$ bees; HM: $8700 \pm 1700$ bees; $P>0.05$, U-test). Within the CR-method, the nuc and the mother colony are reunited before wintering. However, these colonies lost about two-thirds of their bees just before winter (winter population of CR: $13200 \pm 5300$ bees; HM: $8800 \pm 3500$ bees). If the varroa infestation levels are high, a specific mite control in August and September (preferably with formic acid) is crucial for the survival of the colony.

33. Spraying boron into blooming oilseed rape - a risk for honey bees? W. Dyrba ${ }^{1}$,
T. Augustin ${ }^{2}, \quad$ R. Siede ${ }^{3} \quad\left({ }^{1}\right.$ Bienenzuchtzentrum Bantin, 19246 Bantin, Germany; ${ }^{2}$ Landesbetrieb Hessisches Landeslabor, 34128 Kassel, Germany; ${ }^{3}$ Landesbetrieb Landwirtschaft Hessen, 35274 Kirchhain, Germany)

Oilseed rape is a crop with a huge demand for boron (B). Sandy soils tend to be B-deficient, therefore supply of B is recommended. Some growers combine the application of $\mathrm{B}$ with pesticide spraying at flowering. However, exposure to B can be detrimental for insects. This study aims to test whether B-spraying has side-effects on bees. In May 2009, we placed six colonies at the edges of a 10 ha rape crop in full bloom, which was sprayed with $1 \mathrm{~kg}$ Foliarel $^{\circledR}$ (containing $210 \mathrm{~g}$ water soluble B) per ha two days after colony establishment. Six control hives were positioned close to a nonfertilized rape field. Honey and bee bread were sampled before and 1, 5, and 7 days after application. Colony strength was estimated before and 24 days after B application. Samples were decomposed in a closed-vessel microwave digestion system using hydrogen fluoride (HF). B and 12 other elements (Al, $\mathrm{Cd}, \mathrm{Cr}, \mathrm{Cu}, \mathrm{Fe}, \mathrm{K}, \mathrm{Mn}, \mathrm{Ni}, \mathrm{P}, \mathrm{Pb}, \mathrm{S}$, and $\mathrm{Zn})$ were determined using the Inductively $\mathrm{Cou}-$ pled Plasma Mass Spectrometry (ICP-MS) technique. The experimental hives and the control hives did not differ statistically with respect to the number of bees ( $P=0.87$ Proc GLM repeated SPSS $)$ and of open- $(P=0.123)$ or capped brood $(P=0.089)$. The $\mathrm{B}$ contents of honey $(P=0.656)$ and bee bread $(P=0.665)$ of both groups were not statistically distinguishable, but they were higher than previously reported which might be a consequence of the efficient HF digestion. The amounts of the 12 other elements corresponded approximately to the levels from known floral honeys. Our results on the B-sprays in bloom give no indication of adverse or promoting effects on bees or the quality of their products.

34. An immunotoxicological study on honey bees exposed to common pesticides. J. Pinkas, R. Siede, M. Meixner, R. Büchler (Landesbetrieb Landwirtschaft Hessen, 35274 Kirchhain, Germany)

Bees rely upon a functional immune system to defend themselves against pathogens. Certain pesticides are known to modulate immunity, as it has been shown for organophosphorous compounds in rodents and aquatic organisms. Comparable effects are hypothesized to occur in bees, thus making them more vulnerable to agents of diseases and, perhaps, cause massive colony die-offs. To test this 
hypothesis, we exposed bees in hoarding cages to three commonly used agrochemicals: the insecticidal neonicotinoid Thiacloprid, the fungicide Boscalid, and the herbicide Terbuthylazin. Cages were filled each with 15 freshly emerged worker bees. We orally administered five different doses of each pesticide mixed with syrup, ranging from the known LD50 to $1 \mu \mathrm{g}$ of each pesticide. The experiment lasted seven days. Mortality was recorded every day. Only bees exposed to the highest concentrations of each pesticide suffered significantly elevated mortalities. The immune system of the surviving bees was challenged by injection of Paenibacillus larvae. After an incubation period of $10 \mathrm{~h}$, the bees were sacrificed, their RNA was extracted, and the expression of the genes encoding for hymenoptaecin (Hym) and for prophenoloxidase (ProPo) were determined by real-time PCR. Hym was upregulated approximately 700 -fold upon injection of $P$. larvae. Expression of ProPo was not induced. The level of gene expression did not differ significantly between bees subjected to pesticides and control bees without pesticides (Kruskal Wallis Test $P>0.05$ ). None of the pesticides tested showed immuno-modulatory effects. Further studies are required to expand the tests towards other immunity related parameters, especially the cellular defence, and also to test additional pesticides.

38. Development of a SNP assay for Varroa tolerance in the honey bee. A. Spötter ${ }^{1}, P$.

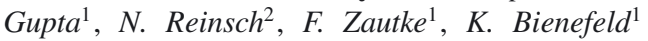
$\left({ }^{1}\right.$ Länderinstitut für Bienenkunde Hohen Neuendorf e.V., Friedrich-Engels-Straße 32, 16540 Hohen Neuendorf; ${ }^{2}$ Leibniz-Institut für Nutztierbiologie, Wilhelm-Stahl-Allee 2, 18196 Dummerstorf, Germany)

For a long time, the ectoparasitic mite Varroa destructor has posed one of the biggest threats for the honey bee worldwide. It reproduces in capped brood cells and feeds on the haemolymph of pupae. A naturally occurring but rare behaviour of honey bees against Varroa is the uncapping of infested brood cells and the removal of the contained larvae. In this way, mite reproduction is prevented. The aim of this project is to identify genetic markers in the genome of the honey bee that are associated with the trait "removal of varroa-infested brood". Using Next Generation Sequencing of DNA-pools of trait-bearers and controls, 28000 genetic markers (single nucleotide polymorphisms; SNPs), taken from a list of the Honey Bee Genome Project, were identified that are associated with the investigated trait. These SNPs are an ideal system for the fol- lowing investigations and they will be used for the construction of a SNP-Chip. The high-throughput screening of SNP-chips with genome DNA from honey bees should enable the detection of genes influencing the varroa specific defense behaviour. These genes, and the behavioural differences they effect, should be elucidated by molecular genetic methods. The results of this project - with the inclusion of beekeeping practice - will be used to improve the breeding of varroa-tolerant honey bees.

41. Influence of the position and number of Apidea type mating hives on the mating success of Apis mellifera carnica queens on the island mating station Unije, in May 2009. $D$. Šekulja (Polytechnic of Rijeka, Trpimirova 2/V, 51000 Rijeka, Croatia)

When hundreds of mating hives are placed close to each other, drifting of queens is normally accepted as one of the factors that are negatively influencing the mating success, especially when mating hives are placed in blocks. The influence of the position and number of Apidea type mating hives (in blocks of eight to 12) on the mating success was studied on 712 queens on the island of Unije. Due to the long transport and limited availability of suitable locations on the island for placing mating hives, it has proven to be convenient to use the system of eight mating hives in block (four mating hives per floor). To observe eventual differences in mating success based on the position of the mating hives in blocks of eight, mating success was separately recorded on the lower and upper floors. In blocks of 12 , it was separately recorded for the lower, middle, and upper floor. It was also calculated whether there was a difference in mating success between blocks of eight or 12 (i.e., whether it would make sense to use mating hives in blocks of 12). Some blocks of eight were placed on the ground to compare their mating success with those placed on posts above the ground. In blocks of eight Apidea placed on posts $(\mathrm{n}=640)$, the average mating success was $54.1 \%$. On the upper floors, it was $57.2 \%$, and on the lower floors, it was $50.9 \%$. When placed on the ground $(n=32)$, mating success on the lower floors was $68.8 \%$ and on the upper floors only $43.8 \%$. In blocks of 12 Apidea $(n=40)$, mating success was $55.0 \%$. On the lower floors it was $75.0 \%$, on the upper floors $50 \%$, and $40 \%$ in the middle floors. However, there was no significant difference in average mating success rate between the blocks of eight (54.1\%) and 12 Apidea (55.0\%).

42. Live-cell imaging and physiological characterization of brain cell transmitter-receptors. 
S. Himmelreich, M. Hähnel, B. Grünewald (Institut für Bienenkunde Oberursel der Polytechnischen Gesellschaft, FB Zell- und Neurobiologie, GoetheUniversität Frankfurt am Main, Germany)

Two structures in the insect brain known to be involved in learning and memory formation are the antennal lobes (AL) and the mushroom bodies (MBs). Also, some of the neuronal components involved in the modulation of these structures, such as GABAergic inhibitory neurons and the octopaminergic VUMmx1 neuron, representing the reward pathway for appetitive learning in the honeybee brain, have been identified. To investigate the cellular basis of modulatory processes possibly involved in learning and memory formation, we performed calcium imaging- and patch clamp recordings from cultured pupal AL cells and MB intrinsic neurons (Kenyon cells, KC). Coincident activations of membrane receptors are thought to be the mechanisms of cellular plasticity. Using in vitro experiments, we co-applied the main excitatory transmitter acetylcholine (ACh), together with the inhibitory transmitter, $\gamma$-amino buteric acid (GABA), or the biogenic amine, octopamine (OA). We asked how and to what extend are the ACh-receptors modulated by GABA- and OA-receptor activity, which are co-expressed in projection neurons and $\mathrm{KC}$. During imaging experiments, $\mathrm{Ca}^{2+}$ transients were evoked in cultured AL neurons and KC by applications of ACh. Preliminary results show that coapplication of GABA reduced the amplitudes of the ACh-induced $\mathrm{Ca}^{2+}$ signal, while co-application of $\mathrm{OA}$ almost completely abolished $\mathrm{Ca}^{2+}$ transients in $\mathrm{AL}$ cells and in KC. During patch clamp recordings, ionic currents were induced by applications of ACh or GABA. Applications of OA before GABA or before $A C h$ reduced the peak amplitude of $\mathrm{I}_{\mathrm{ACh}}$ and $\mathrm{I}_{\mathrm{GABA}}$ in $\mathrm{KC}$ and in AL cells. Thus, we showed that $\mathrm{KC}$ and $\mathrm{AL}$ cells express $\mathrm{ACh}$ - and GABAreceptors, which are modulated by OA. This finding supports the idea that learning-related plasticity occurs both in antennal lobe neurons and mushroom body Kenyon cells. In further experiments, we plan to verify our results so far by applying blockers and agonists of ACh and GABA receptors. We aim to develop a preparation for simultaneous $\mathrm{Ca}^{2+}$ imaging and patch clamp recordings to analyze the underlying processes of intracellular $\mathrm{Ca}^{2+}$ signals and their role in olfactory learning and memory.

43. Analysis of honeybee locomotion behaviour. G. Radspieler, M. Szopek, S. Hahshold, R. Thenius, T. Schmickl, K. Crailsheim (Department of Zoology, Universitaetsplatz 2, 8010 Graz, Austria)
Temperature is an important factor in the bee hive. Honeybees have an age-dependent temperature preference and thus prefer different locations in the hive. Young honeybees have a preference for $36{ }^{\circ} \mathrm{C}$, which is the typical temperature of the brood nest. We hypothesize that this preference partially mediates their affinity to this area and expect that the local temperature has an influence on their locomotion and aggregation behaviour. In order to investigate the temperature dependency of the locomotion behaviour, we carried out a sequence of experiments with individual young (12- to 24-hourold) honeybees (Apis mellifera carnica) moving in a circular arena. We tested 146 bees at different ambient temperatures between 28 and $38{ }^{\circ} \mathrm{C}$. We released them at the center of the arena and recorded them for 10 minutes under infrared light. We then processed the recordings automatically and determined the bees' positions in the arenas with a resolution of $1 \mathrm{~s}$. Finally, we extracted a number of behavioural parameters from the bees' trajectories and evaluated their moving speed at different temperatures. Generally, the tested bees' motion speed was normal distributed with a mean value of $2.0 \mathrm{~cm} / \mathrm{s}$ and a standard deviation of 1.80 . Moving bees (deliberately defined as bees moving with at least $0.5 \mathrm{~cm} / \mathrm{s}$ ) were moving at an average speed of $2.4 \mathrm{~cm} / \mathrm{s}$ with a standard deviation of 1.73 . Temperature had no significant influence on the motion speed. The average motion speeds were approximately evenly distributed over the tested temperature intervals. However, resting behaviour (motion speed is less than $0.5 \mathrm{~cm} / \mathrm{s}$ ) occurred more frequently near the temperature preference (peak is $87.8 \%$ resting behaviour at $35.0^{\circ} \mathrm{C}$ ). We interpret this behaviour as a proximate mechanism for the bees' ability to form aggregations at areas of optimal temperature.

44. Cooperative thermotaxis in honeybees: social gradient vs. temperature gradient. $S$. Hahshold, G. Radspieler, R. Thenius, T. Schmickl, K. Crailsheim (Artificial Life Lab of the Department of Zoology, Karl-Franzens University, 8010 Graz, Austria)

It has been shown that groups of young honeybees $(<30 \mathrm{~h})$ collectively locate themselves at their preferred temperature $\left(36^{\circ} \mathrm{C}\right)$. Thus, they are able to discriminate temperatures. We conducted experiments to test the influence of a social gradient on the cooperative thermotaxis in honeybees. Young bees were introduced to a temperature gradient and also to a social gradient (generated with immobilized bees). Experiments were performed in 
a circular arena. We generated a temperature gradient with heat lamps to establish a global $\left(36^{\circ} \mathrm{C}\right)$ and a local $\left(32{ }^{\circ} \mathrm{C}\right)$ optimum. We used an acrylic cage with fence walls and bees inside to generate a social gradient. An empty cage was introduced to the global optimum as a control. We investigated two different group sizes: six $(n=11)$ or $24(n=$ 13) bees. The experiments lasted for $30 \mathrm{~min}$. Afterwards, the bees around the global and the local optimum were counted. We showed that for both group sizes, the proportion of aggregating bees in the local optimum was significantly higher than in control experiments. Near the global optimum, the proportion of bees decreased when there was a cage with bees in the local optimum (groups of 24: $P<0.0$ ?; groups of six: $P=0 . ?$ ?; Mann-Whitney-U-Test). In the control experiments with empty cages, we found that empty cages have no influence on the aggregation behaviour of bees. In a temperature gradient (30-36 ${ }^{\circ} \mathrm{C}$ ), aggregation behaviour of young honeybees is also influenced by a social gradient; bees were more likely to aggregate in the area with caged bees. We showed for the first time that a social gradient influences the aggregation behaviour of young bees more strongly than does a temperature gradient. Moreover, we were able to experimentally influence collective decision-making of the bees; induced by the presence of immobilized bees, mobile bees did not aggregate in their optimum but instead in the area with suboptimum conditions.

45. Cooperative thermotaxis in honeybees: flexible group behaviour in a dynamic environment. M. Szopek, G. Radspieler, R. Thenius, T. Schmickl, K. Crailsheim (Artificial Life Lab of the Department of Zoology, Karl-Franzens University, 8010 Graz, Austria)

Young bees typically locate themselves at their temperature preference of $36^{\circ} \mathrm{C}$ in a steep thermal gradient $\left(10{ }^{\circ} \mathrm{C}-36{ }^{\circ} \mathrm{C}\right)$. However, in a flat thermal gradient $\left(30{ }^{\circ} \mathrm{C}-36{ }^{\circ} \mathrm{C}\right)$, only one-third of individual, young honeybees are found close to $36{ }^{\circ} \mathrm{C}$, whereas the majority exhibit a slight uphill tendency in the gradient. Experiments showed that groups of bees are able to cluster at $36{ }^{\circ} \mathrm{C}$ even in a flat gradient. We investigated the flexibility of the group behaviour of young bees $(\leq 30 \mathrm{~h})$ in a dynamical flat thermal gradient generated with heat lamps. Experiments started with a complex gradient having a global optimum at $36{ }^{\circ} \mathrm{C}$ (left aggregation zone; $11.2 \%$ of the total arena area), a local optimum at $32{ }^{\circ} \mathrm{C}$ (right aggregation zone; $11.2 \%$ of the total arena area) and an ambient temperature of $30{ }^{\circ} \mathrm{C}$. After $30 \mathrm{~min}$, we turned off the heat lamp so that, after a cooling phase, the $32{ }^{\circ} \mathrm{C}$ peak became the new global optimum. One experiment lasted $105 \mathrm{~min}$, and we tested groups consisting of 64 bees $(n=20)$. Bees aggregated collectively under the $36{ }^{\circ} \mathrm{C}$ lamp within the first $30 \mathrm{~min}$. After this heat lamp had been turned off, they collectively 'reconsidered' their previous decision and aggregated at the new global optimum of $32{ }^{\circ} \mathrm{C}$, which had almost been ignored before. After a cooling period, the bees wandered from the zone on the left to the zone on the right, while the fraction of bees outside these two zones increased just slightly. The fractions of bees in the left and in the right zone were significantly different after 7, 30, and $105 \mathrm{~min}$ (U-test, $P<0.001$ ). The fractions of bees in the left zone after $30 \mathrm{~min}$ and the right zone after $105 \mathrm{~min}$ did not differ (U-test, $P>0.05$ ). Our analysis indicated that the two zones compete for the free bees and that bees collectively choose the global optimum. We showed that groups of bees are not only able to discriminate between a local- and a global optimum, but also they react flexibly to changing conditions.

47. Honeybees are not tea drinkers. D. Ahrens, N. Höcherl, H. Gätschenberger, K. Azzami, J. Tautz (BEEgroup, Biozentrum Universität Würzburg, 97074, Germany)

Humans use herbal tea against disease and to improve their health. The use of tea in beekeeping is new. Is this approach suitable to support the vitality of bees? Thirteen colonies were fed with a sugar solution (3:2; Group S) and 13 other colonies with the same sugar solution spiked with $3 \%$ herbal tea and $10 \%$ flower honey (Group T\&H). The teas were prepared separately and then mixed in one tea added to the sugar solution. The flowers of chamomile, dandelion and yarrow were brewed up as tea. A valerian tincture was diluted with water. The stinging nettle, oak bark and the horsetail were steeped in cold water. The size of the colonies was estimated at three times with the "Liebefeld method". The level of Nosema infection at time of winter death was investigated as well as in a sample of live bees from the side comb in April. To estimate immune competence we examined the existence of storage proteins and antimicrobial peptides at two times. Heamolymph samples were taken from 30 bees of each colony and analyzed with a gel electrophoresis. The statistical evaluation of the size of the colonies was based on factors such as winter survival and spring development. Winter survival of Group S (83.6\%) was similar to Group T\&H (89.5\%). The spring development 
of Group S was clearly enhanced as compared to Group T\&H (164.9\% vs. $126.3 \%)$. The winter death of Group T\&H was significantly more associated with levels of Nosema spores. The second sample of Group T\&H from the side comb in April was not significantly more affected with Nosema spores but it still showed the same tendency. The immunecompetence of both groups was equal. The results imply that adding tea to the winter food has no positive effect on the vitality of bees. Instead it seems that food additives such as tea may even harm bees.

48. Delayed development of artificially reared honeybees. U. Riessberger-Gallé, J. Vollmann, K. Crailsheim (Department of Zoology, Universitaetsplatz 2, 8010 Graz, Austria)

Various methods to raise honeybee larvae artificially are described in the literature. We used a slightly modified method described by Aupinel et al. (2005, Bull. Insect. 58, 107-111) and compared the development of artificially raised larvae to the development of naturally raised larvae described by Myser (1954, Ann. Entomol. Soc. Am. 47, 683-711). The investigations were carried out in 2007 using two colonies of Apis mellifera carnica Pollmann. We transferred 5-10 h old larvae into plastic queen cups and fed them 6 days with defined quantities of a diet consisting of royal jelly and various concentrations of sugar-yeast dilution, once a day. We kept them at $34.5^{\circ} \mathrm{C}$ and $95 \% \mathrm{RH}$ till the age of $7.5 \mathrm{~d}$, later the $\mathrm{RH}$ was decreased to $70-75 \%$. Brood samples were taken, the development of mouthparts and wing buds was investigated and the morphological status was classified (two colonies, $\mathrm{n}=24-72$ per age class). We found differences of the development of the mouthparts and wing buds at the age of 3-3.5 d. Only about half of the investigated individuals showed the developmental status of early $3 \mathrm{~d}$ old larvae, the others were delayed in their development. In the group of $4-4.5 \mathrm{~d}$ old artificially raised larvae $87.6 \%$ showed the developmental status of late $3 \mathrm{~d}$ old naturally raised ones, all others were even more delayed in their development. The development of mouthparts and wing buds of older larvae more or less corresponded to the age but their metamorphosis to pupae showed a delay of 1-2 days compared to larvae in a colony. Nevertheless of all these observed delays in larval development the individuals seamed to be sufficiently nourished, and they had the potential to make up their delay as we observed their eclosure 18 days after hatching from the eggs.

51. NRPS and PKS in Paenibacillus larvae. E. Garcia-Gonzalez ${ }^{1}$, J. Nachtigall ${ }^{3}$, R. Borriss ${ }^{2}$,
R. Süssmuth ${ }^{3}$, E. Genersch ${ }^{1}\left({ }^{1}\right.$ Institute for Bee Research, Friedrich-Engels-Str. 32, 16540 Hohen Neuendorf, Germany; ${ }^{2}$ Humboldt Universität, Bakteriengenetik, Chaussestr. 117, 10115 Berlin, Germany; ${ }^{3}$ Institut für Chemie, Technische Universität, Franklinstr. 28/29 10587 Berlin, Germany)

American foulbrood (AFB) is considered the most contagious and destructive infectious disease in honeybees, caused by the gram-positive, sporeforming bacterium Paenibacillus larvae. P. larvae harbours giant gene clusters that code for polyketide synthases (PKS) and nonribosomal peptide synthetases (NRPS). These enzymatic complexes are responsible for the biosynthesis of natural products that are implicated in multiple functions such as antibiotic, immunosuppressive, cytostatic and toxic activity. We identified several genome regions encoding putative genes coding for NRPS and/or PKS and assembled three clusters that may be functional in P. larvae. Based on activity assays, we determined that the production of these substances occurred mainly during the stationary phase of bacterial growth, probably coinciding with larval decay. We hypothesize that $P$. larvae requires these substances in order to compete against bacterial or fungal competitors present in the hive, to persist and to be spread.

52. Successful manipulation of Paenibacillus larvae. L. Poppinga, E. Genersch (Institute for Bee Research, Friedrich-Engels-Str. 32, 16540 Hohen Neuendorf, Germany)

The four different genotypes (ERIC I-IV) of Paenibacillus larvae, the causative agent of American Foulbrood (AFB), differ in terms of virulence. Molecular manipulation of $P$. larvae is an important tool to characterize and analyze different infection characteristics of the genotypes. Bacteria are manipulated by the uptake of foreign DNA (plasmids) by transformation. P. larvae, as a gram-positive bacterium, is characterized by its thick cell wall inhibiting transformation efficiency. This condition makes it difficult to transfer plasmid DNA into $P$. larvae-cells. In this work the two plasmids, pHP13 and pDM60, were successfully transferred in both genotypes, ERIC I and ERIC II, by electroporation. Plasmid pHP13 is a commonly used cloning vector whereas pDM60 is a hybrid of a naturally occurring plasmid of $P$. larvae and a sequencing vector. Competent $P$. larvae-cells were prepared, plasmid DNA was added to cell-aliquots, incubated and suspensions were electroporated at high voltage. After regeneration and selective growth on chloramphenicol (pHP13) or tetrazyklin (pDM60), clones 
were isolated and further characterized. PCR- and restriction-analyses revealed a stable manipulation of both genotypes with both plasmids. The successful transfer of foreign DNA into P. larvae permits a variety of possibilities to investigate infection differences.

53. Expression of Plt, a ADP-ribosylating toxin of Paenibacillus larvae. L. Poppinga, A. Fünfhaus, E. Genersch (Institute for Bee Research, Friedrich-Engels-Str. 32, 16540 Hohen Neuendorf, Germany)

During infection the causative agent of American Foulbrood, Paenibacillus larvae, causes degradation of the intestinal epithelium of honey bee larvae, consequently leading to rounded intestine cells. Simultaneously, the invasion of P. larvae in the hemocoel could be observed. The degradation of the intestine barrier could be caused by ADP-ribosylating toxins, which probably destroy the cytoskeleton and cell-cell contacts of the host. Plt (P. larvae toxin), a ADP-ribosylating AB-toxin, is only synthesized by $P$. larvae genotype ERIC I. AB-toxins are characterized by their A-subunit which arranges catalytic activity, whereas the B-subunit induces translocation and targeting of the host cell. For toxin characterization Plt was cloned in an appropriate expression vector, harbouring promotor-, RBS- and start codon-sequences. The recombinant plasmid was further added to an in vitro expression system (E. coli cell extract), and incubated for translation of the genetic information. SDS-gel-analyses revealed a successful translation of the N-terminal His-tagged protein. Purification of Plt was arranged by the affinity of the His-tag to magnetic nickel particles. After binding, washing and elution of the tagged protein with imidazol it could be visualized on SDS-gels with a mass of about $108 \mathrm{kDa}$. Purified recombinant Plt is now ready for further investigations to analyze $P$. larvae-patho genesis.

54. Proteome analysis (2D-SDS-PAGE) of $\boldsymbol{P}$. larvae. A. Fünfhaus, E. Genersch (Institute for Bee Research, Friedrich-Engels-Str. 32, 16540 Hohen Neuendorf, Germany)

Phenotypical differences between the four common genotypes ERIC I - ERIC IV of Paenibacillus larvae ( $P$. larvae), the causative agent of American Foulbrood (AFB), are known. They vary from each other in virulence, metabolism as well as in the morphology of their colonies and spores. Furthermore genetic differences between these P. larvae genotypes were identified using the PCR based method of Suppression Subtractive Hybridization
(SSH). Proteome analysis of the genotypes ERIC I ERIC IV reveals information about proteins that are responsible for phenotypical variability. 2DSDS-PAGE-analysis followed by mass spectrometric investigations of conspicuous protein spots in the gel is a suitable method to identify proteins responsible for phenotypical characteristics of the $P$. larvae genotypes. 2D-SDS-PAGE-examinations provide the separation of proteins from a complex mixture of proteins on the basis of the following two parameters. During the first dimension, the isoelectric focusing (IEF), separation occurs by the isoelectric point of the proteins. The second dimension is a SDS-PAGE. In this electrophoresis the protein mixture is separated by mass. Different proteins are typically not similar in both their isoelectric point and their mass so that a high resolution can be achieved. We successfully established (i) a protein extraction method for $P$. larvae suitable for subsequent 2D-SDS-PAGE analysis and (ii) reproducible 2D-SDS-PAGE-analyses of these protein preparations. We will now determine the master protein patterns of the four P. larvae - genotypes isolated from liquid bacterial cultures as well as isolated from infected honey bee larvae in order to elucidate the proteome characteristic for certain life styles of different $P$. larvae genotypes.

55. Horizontal transmission of DWV to adult bees. N. Möckel, S. Gisder, E. Genersch (Institute for Bee Research, Friedrich-Engels-Str. 32, 16540 Hohen Neuendorf, Germany)

DWV (deformed wing virus) is a honey bee virus also pathogenic for bumble bees. Several transmission routes could be experimentally demonstrated: vertical transmission occurs via drone sperm or queen eggs, horizontal transmission occurs via the larval food, and vectorial transmission to pupae is facilitated by Varroa destructor. Normally, DWV infections are covert, i.e. the presence of the virus can be shown in the absence of disease symptoms. Overt infections are characterized by clinical disease symptoms (crippled wings and virus infection of the brain) and are dependent on the vectorial transmission of the virus during the pupal stage of development. Here, we analyzed further horizontal transmission routes for DWV: oral and vectorial transmission to adult bees. For this purpose, quarantine, DWV-free adult bees were fed or injected with virus suspension. Mock infected bees served as control. Molecular analysis of bees which obtained DWV via feeding or injection revealed that both transmission routes can be successful although the efficiency of infection was different. 
58. Histopathology of Nosema-infected bees. S. Gisder, N. Möckel, E. Genersch (Institute for Bee Research, Friedrich-Engels-Str. 32, 16540 Hohen Neuendorf, Germany)

Microsporidia are obligate intracellular, spore forming pathogens infecting vertebrates and, for the most part, invertebrates. The European honey bee (Apis mellifera) can be affected by two microsporidia, Nosema apis and Nosema ceranae, leading to nosemosis, an infection of midgut epithelial cells. Results from Spain show that $N$. ceranae is highly virulent in Apis mellifera and infections were correlated with severe colony losses. Despite the importance of these two microsporidian honey bee pathogens, comprehensive and especially comparative histopathology studies for $N$. apis and $N$. ceranae infected bees are missing. In this study the molecular-cytogenetic method of Fluorescence in situ hybridization (FISH) was performed to detect specific $N$. apis and $N$. ceranae in midgut tissue sections. Midguts from bees which tested positive for either $N$. apis or $N$. ceranae were fixed in $4 \%$ paraformaldehyde, embedded in resin from Kulzer, dissected in $3 \mu \mathrm{m}$ semi-thin dissections and hybridized with fluorescence-dye labeled oligonucleotides. Hybridization was performed with $16 \mathrm{~S}$ rRNA targeted, Nosema spp. specific probes and a universal probe targeting the 18S rRNA of eukaryotic cells. Nuclei were stained with DAPI. Analysis of hybridized tissues was performed using a semi-confocal fluorescence microscope. The detection of vegetative stages and spores of Nosema spp. in epithelial midgut cells allowed insights into the pathogenic process in infected tissues.

59. Harmful fading away or beneficial shakeout? A two-years-study of population dynamics of honey bee colonies infected with Nosema ceranae. P. Aumeier ${ }^{1}$, J. Lipka ${ }^{1}$, S. Niederdrenk ${ }^{1}$, K. Porbeck ${ }^{1}$, E. Genersch ${ }^{2}$, O. Boecking ${ }^{3}$, G. Liebig $^{4}$, W.H. Kirchner ${ }^{1}$ ( ${ }^{1}$ Fakultät für Biologie und Biotechnologie, Ruhr-Universität Bochum, Germany; ${ }^{2}$ Länderinstitut für Bienenkunde Hohen Neuendorf e.V., Germany; ${ }^{3}$ Institut für Bienenkunde Celle; ${ }^{4}$ Landesanstalt für Bienenkunde Hohenheim, Germany)

Nosema apis (Zander) is generally considered to be mostly harmless for Apis mellifera. However, relatively little is known about the virulence of Nosema ceranae or the impact of this species on honey bee population dynamics (Fries, 1996). Forty and 78 bee hives, located in Bonn (2000) and Bochum (2008 and 2009), Germany, respectively, were monitored regarding their colony de- velopment (Liebefeld method) and their infection with Nosema ceranae. In our honey bee colonies in Western Germany, the distribution pattern of the two Nosema species clearly shifted from 2000 (100\% N. apis) to 2009 (March 2008: 10\% N. apis; March 2009: 100\% N. ceranae). In contrast to $N$. apis, $N$. ceranae did not show a characteristic seasonal progression of the proportion of infected colonies or bees. Neither the individual bees' degree of infection with $N$. ceranae nor the mean quantity of spores found per colony correlated with the daily loss of adult bees. Thus, we could not detect a pronounced pathogenicity of $N$. ceranae or find a beneficial effect of the daily bee loss. In contrast to previous studies, the year-round infection with Nosema ceranae did not affect the development of the observed honey bee colonies in this field study.

61. Honey bee colony development and infestation with Nosema spec. after manipulation of the brood during spring 2009. D. de Craigher, $G$. Liebig (Apicultural State Institute, 70593 Stuttgart, August-von-Hartmann-Str. 13, Germany)

Infestations with Nosema often appear during spring when the winter bees are replaced by summer bees. The alternation between warm and cold weather periods apparently promotes the infection. This was the case in 2009 when due to the cold March the bees delayed intensive brood rearing until early April with a corresponding delay in the change from winter to summer bee population. We tested the hypothesis that a longer life span and longer period of brood care of the winter bees lead to an increase of Nosema spec. infestations. On April 26th, we exchanged all frames with open brood from 5 colonies (group "V") for frames with capped brood from 5 other colonies (group "O"). Five colonies remained untreated as control (group "K"). Therefore, the replacement of winter bees should take place significantly earlier in "V" compared to "O" and the conditions for an increase of nosema infestations should be better in "O". After 12 days the strength of colonies was estimated according to the "Liebefeld Method", samples of 15 bees per colony were analyzed individually by light microscope and the average number of nosema-infested bees per group was calculated. Twenty-one days later the strength of colonies was estimated again. From April 26th to May 8th the infestation level in "V" declined from 18 to $11 \%$ and in " $\mathrm{K}$ " from 18 to $13 \%$, on average. However, in "O" the infestation increased from 17 to $21 \%$ (not significant). There was no significant correlation between the nosema infestation and the 
relative mortality of the bees. From April 26 to May 8 the "O" colonies showed the lowest mortality followed by "V" and "K". Thirty-three days after the start of the experiment, the "O" colonies had 25200 bees, the "V" colonies 21100 and the "K" colonies 29000 bees, on average. The removal of capped brood and the addition of open brood during the change from winter to summer bee population (group "O") led to a slight increase in nosema infestations, but had no negative effects on the colony development. According to the estimates of bees and brood, the "O" bees lived even longer compared to the "V" bees despite of their comparatively higher nosema infestation.

62. Pathogenesis and behaviour of honey bees infected with Nosema ceranae. S. Deckert, P. Aumeier, W.H. Kirchner (Fakultät für Biologie und Biotechnologie, Ruhr-Universität Bochum, Germany)

Nosema ceranae presumably has infected Apis mellifera since 1998. Up to now, little is known about the pathogenesis in this new host species, as well as about its sublethal effects on its behaviour. $N$. ceranae and $N$. apis spores of different infective doses and after different periods of storage (in bees, at $-20{ }^{\circ} \mathrm{C}$ ) respectively, were fed to at least 40 newly hatched bees each. The pathogenesis was recorded for 16 days p.i. in cage experiments. Furthermore, we studied the unconditioned proboscis extension reflex of 60-106 healthy or infected bees and tested olfactory learning, discrimination and retention in groups of $60-270$ bees using the conditioned proboscis extension reflex paradigm. The proportion of infected bees as well as the number of spores per bee was correlated with the infective dose (Mann-Whitney U-Test, $P<0.05$ ). Nosemaspecies expressed different infective rates. Honey bees, infected with $N$. apis, had maximum numbers of spores in the midgut 8 days p. i., whereas $N$. ceranae spores reached maximum spore loads 12 days p. i.. Spores of $N$. ceranae severely lost infectivity after a one-week storage at $-20^{\circ} \mathrm{C}$. However, prolonged freezing could not cause any further reduction of virulence (Mann-Whitney U-Test, $P<0.05)$. An infective dose of $10^{3}$ spores per bee turned out to be sufficient to generate a reliable infection. Honey bees, either naturally or artificially infected with $N$. ceranae, expressed unconditioned reflexes more frequently than healthy bees. However, although infected bees responded better to the antennal sucrose stimulus, their learning, discrimination and retention performance was poorer than that of uninfected controls.
65. First global estimation of honey bee colony losses. $K$. Crailsheim, R. Brodschneider (Department of Zoology, Karl Franzens University Graz, Universitätsplatz 2, 8010 Graz, Austria)

At the 41st congress of Apimondia, held in Montpellier, 15-20 September 2009, we conducted a survey among the attendants regarding their honey bee colony losses during the winter 2008/2009 and later in the year. Copies of a questionnaire, written in four languages (English, French, Spanish, German) were distributed. In total, we obtained data on 171 beekeeping operations across the world, predominantly from Europe (78.9\%). Respondents held on average 162.7 colonies, including operations handling one to 4800 colonies. A total of 5081 $(=18.7 \%$, 95\% confidence interval: $12.9-24.5 \%)$ of 27163 corresponding colonies were lost during the winter $2008 / 2009$. Of the remaining 22082 colonies, $946(=4.3 \%, 95 \%$ CI: $1.3-7.3 \%)$ were lost by September 2009. Overwinter losses hence made up the majority of colony losses. A portion of $5.7 \%$ (95\% CI: $2.2-9.2 \%$ ) or 1559 colonies were lost exhibiting two symptoms of colony collapse disorder (CCD): the presence of brood and food but only few adult bees left. According to our study, beekeeping operations experienced a total decline of $22.2 \%$ (95\% CI: $16.0-28.4 \%$ ) of their managed honey bee colonies from autumn 2008 to summer 2009. Sample sizes were low in many regions, but based on 3 or more respondents, Belgium, Brazil, Chile, Germany, France, Italy, Netherlands, Norway, Switzerland, Spain, United Kingdom, Uruguay and the USA experienced losses of more than $20 \%$ of colonies between autumn 2008 and summer 2009. Cases of CCD (>10\%) were reported from France, Italy, Norway and the USA.

66. A closer look - Honey bee colony losses in Germany in 2009/10. P. Aumeier ${ }^{1}$, O. Boecking ${ }^{2}$, G. Liebig ${ }^{3}$ ( ${ }^{1}$ Ruhr-Universität Bochum; ${ }^{2}$ Institut für Bienenkunde Celle; ${ }^{3}$ Landesanstalt für $\mathrm{Bi}$ enenkunde Hohenheim, Germany)

As in past years, dramatic honey bee colony losses were expected for the winter 2009/2010. To contribute to a cause analysis we performed an anonymous census in February and March 2010 all over Germany. The data are based on questionnaires filled in by 589 beekeepers managing 10143 colonies. In Northern and Western Germany in 2009 the honey yield per colony was satisfactory (33 and $37 \mathrm{~kg}$, respectively), whereas the yield in the South was only $18 \mathrm{~kg}$. There were no regional differences in other parameters such as age of beekeeper, beekeeping experience 
or number of wintered colonies. Uniformly, beekeepers stated about $15 \%$ colony loss during winter. Regional differences, environmental factors and activity of beekeepers associations did not impact losses. Rather, management techniques seemed to impact extreme deviations in loss $(0 \%$ or $100 \%$ loss, respectively). The main factor appeared to be the type of acaricides applied and the mode of application, both clearly influenced by regional patterns and advisory services of bee institutes. Colony losses of more then $10 \%$ can be avoided if (a) drone brood is used as mite trap and is eliminated accurately (b) formic acid (FA) is applied in late summer (either 3-8 times $60 \%$ FA or $2-3$ times $85 \%$ FA) just before the rearing of overwintering bees, and (c) treatment in winter is carried out by trickling oxalic acid. Twenty-seven\% of colonies died if only thymol was admistered in summer. Similarly, repeated trickling of oxalic acid in summer or foregoing winter treatment gave rise to considerable bee losses. This survey gives an impression of the diversity of mite treatment regimes applied by German beekeepers. However, it illustrates the resoundingly positive effect of effective treatment of Varroa destructor on the overwintering success of honey bee colonies.

73. Bee legs and feathers as natural model for absorbent textiles. V. Grabarek, H. Schmied, D. Wittmann* (Institute of Crop Science and Resource Conservation, Ecology of Cultural Landscape, ZooEcology, University of Bonn, Melbweg 42, 53127 Bonn, Germany) Email: Grabarek@uni-bonn.de, Schmied@uni-bonn.de,Wittmann@uni-bonn.de

The ability to collect and release oil from flowers is a remarkable feature of bees. Male neotropical orchid bees (Euglossini) are well known for their unique ability to collect and temporarily store lipid scents from orchids and other flowering plants with specialized hairs on their tarsomeres $2,3,4$ and 5. These tarsomeres exhibit bristles to scratch open odor glands and long hairs with a brush like tip to store the liquid. We discuss the function of this structure and compare them with structures of neotropical oil bees.

Sand grouses (Pteroclididae) are a family of dove-like birds which live mainly in semi-deserts. In the breeding season male adults absorb water with their belly-feathers and carry it to the young which drink out of the plumage. This exclusive water transport is possible because of specialized feathers. In dry conditions the fine Barbule are interlaced in the plane of the feather. When they are wetted the feather-hairs change their 3-D structure, so that water can be stored within layers of feathers. These studies are part of a project on Biomimetics with the aim to design new technical structures for oil absorption.

74. World Varroa challenge Toulouse (France). J. Kefuss (Le Rucher D'Oc, 31200 Toulouse, France)

In 1993 we began selecting bees for low receptivity and sensibility to Varroa destructor. All chemical treatments were stopped in 1999 ("Bond Test"). After losing over two-thirds of our hives we reduced losses by breeding from survivors. At present (2009) mite populations are less than 5\% and it is not economic to treat. Hygienic behavior at 24 hours has improved, honey production is good and winter losses at $15 \%$ are less than the $23 \%$ for others in same area that treat. The "Bond" or "live and let die test" gives clear results but due to fear most breeders refuse to use it. In that sense it is not a good test. To limit the financial impact of the "Bond Test" we developed the "Soft Bond Test" (Kefuss et al., 2009, Apimondia Montpellier Scientific Program, p. 82). We held a World Varroa Challenge near Toulouse to independently verify our selection results. Hives $(600+)$ were located in a zone exposed to mites from other beekeepers. Challengers randomly chose hives and time spent controlling for mites. One cent was paid for every mite found dead or alive. A provisional budget of 100 cents was reserved to cover the costs of paying for mites. Free meals and hay to sleep on were provided. Fifty-five challengers (12 countries) required over 100 hours to find 109 mites. Winners were Clive de Bryne (England) 20 mites, Seth Rick (USA) 17 mites, Jose Manuel Docampo Rovetro (Spain) 16 mites and Ralph Buchler (Germany) 12 mites. It was suggested that given the amount of effort required to find a mite, one euro per mite should be paid. Organizers of future challenges should consider this point because fewer mites will be found as selection progresses. Breeding projects in different parts of the world have demonstrated that it is possible to select bees against Varroa destructor. We believe that it is the moral responsibility of everyone who breeds bees to try to select for mite resistance to reduce chemicals in hives. We owe this effort to future generations of beekeepers. 


\section{Index AU Agib 2010}

Ahrens D., 679, 687

Al-Kahtani S., 678

Augustin T., 678, 684

Aumeier P., 676, 677, 679-681, 683, $684,690,691$

Azzami K., 679, 687

Behrens D., 676

Bergoin M., 679

Beuerle T., 676

Beye M., 676

Bienefeld K., 676-679, 685

Boecking O., 676, 677, 679-681, 684, 690, 691

Borriss R., 679, 688

Bosch C., 679

Brückner D., 680

Brodschneider R., 680, 691

Brunnemann G., 680

Büchler R., 677, 678, 684

Charrière J.-D., 679

Conrad T., 678

Cousserans F., 679

Crailsheim K., 678, 680, 686-688, 691

Dainat B., 677

Danne M., 680

Danner N., 676

de Miranda J.R., 679

de Craigher D., 676, 679, 680, 690

Deckert S., 679, 687

Duchateau M.J., 677

Dyrba W., 678, 684

Ehrhardt K., 678

Erler S.E., 678

Etzold E., 680

Fünfhaus A., 679, 689

Fischer J., 677, 682

Frey E., 676, 679

Fuchs S., 678

Gätschenberger H., 679, 687

Garcia-Gonzalez E., 679, 688

Gauthier L., 679

Gempe T., 676
Genersch E., 677-679, 683, 688690

Gessner C., 676

Gisder S., 677, 679, 683, 689

Grünewald B., 677, 678, 682, 685

Grabarek V., 680, 692

Greco M.K., 677

Gupta P., 678, 685

Gutiérrez A.L., 678

Hähnel M., 678, 685

Härtel S., 676, 678

Höcherl N., 676, 679, 681, 687

Hahshold S., 678, 686

Hartmann T., 679

Hartmann U., 676

Hendriksma H., 676

Himmelreich S., 678, 685

Hokkanen H.M.T., 676, 681

Holt M., 677, 683

Huang Q., 676

Huth- Schwarz A., 678

Illies I., 676, 681

Janke M., 676

Jarosch A., 676

Kästner A., 678

Kamp G., 677

Kast C., 677

Kefuss J., 680, 692

Kirchner W.H., 677, 679, 683, 691, 692

Knauer U., 680

Kraus F.B., 678

Kunz N., 680

Kustermann T., 676, 680

Ladesani M., 679

Larue A., 679

Lattorff M.G., 677, 678, 680

Lichtenberg-Kraag B., 680

Liebig G., 676, 677, 679-681, 684, 691, 692

Lipka J., 679, 690

Masry S., 679

Medrano M., 677
Meffert B., 680

Meixner M., 677, 678, 680, 684

Menzler- Hokkanen I., 676, 681

Möckel N., 679, 689

Moritz R.F.A., 676-678

Müller K., 677, 679

Müller M., 677

Müller R., 680

Nachtigall J., 679, 688

Neumann P., 677, 679

Niederdrenk S., 679, 690

Odemer R., 679

Parsche S., 680

Pflugfelder J., 679

Pinkas J., 678, 684

Popp M., 678

Poppinga L., 679, 688, 689

Porbeck K., 679, 690

Raddatz M., 677, 682

Rademacher E., 677, 682

Radspieler G., 678, 679, 686, 687

Ravallec M., 679

Reetz J., 676

Reinhard A., 676

Reinsch N., 678, 685

Riessberger-Gallé U., 679, 688

Rosenkranz P., 676, 677, 679

Rudolf H., 677

Süssmuth R., 679, 688

Schöning C., 678

Schüttler T., 680

Schiller J., 679

Schmickl T., 678, 679, 686, 687

Schmied H., 680, 692

Schneider C., 678

Schneider S., 677, 682

Schroeder A., 677, 680

Sekulja D., 678, 685

Senge B., 680

Siede R., 676, 678, 681, 684

Spötter A., 678, 685

Stach S., 676

Steffan-Dewenter I., 676, 678

Steiner L., 679

Stolle E., 677

Szopek M., 678, 679, 686, 687 
Tautz J., 676, 678, 679, 681, 687

Tchuenguem F.N., 680

Teglas J., 676

Teuber K., 679

Thenius R., 678, 679, 686, 687

Tournaire M., 679
Vollmann J., 679, 688

von der Ohe W., 676

Wallner K., 676, 680

Wegener J., 677, 679
Wittmann D., 680, 692

Zakour M.K., 679

Zautke F., 678, 685

Ziegelmann T., 677 